Article

\title{
The Impact of the Organizational Culture on Hotel Outsourcing and Sustainable Performance an Empirical Application in the Egyptian Hotel Sector
}

\author{
Mahmoud Gebril Taha and Tomás F. Espino-Rodríguez *(D) \\ Departament of Economics and Business, University of Las Palmas de Gran Canaria, \\ 35017 Las Palmas de Gran Canaria, Spain; gebril44@gmail.com \\ * Correspondence: tomasfrancisco.espino@ulpgc.es; Tel.: +34-938-458-658
}

Received: 21 October 2020; Accepted: 11 November 2020; Published: 20 November 2020

\begin{abstract}
In recent years, the concept of an organizational culture in hotels has held an important position on both a theoretical and practical level because this culture significantly affects organizational performance and the strategies adopted by hotels. Therefore, it is considered one of the key factors in determining hotels' tendency towards outsourcing and sustainable performance. In this study, we aim to analyze the impact of the organizational culture on the level of outsourcing and sustainable performance. To do so, we will use the Competing Values Framework (CVF), which divides organizational culture into four typologies: hierarchical, group, rational, and development cultures. A personal questionnaire was administered to the directors or managers of 114 hotels located in two Egyptian cities: Hurgada and Sharm El Sheikh. The results of the structural model suggest the negative impact of the hierarchical and development cultures on the level of outsourcing. The results show a positive influence of the four types of organizational culture on sustainable performance, suggesting that these hotels have a strong interest in sustainability and the environment. The findings reveal a negative relationship between the level of outsourcing and sustainable performance. Finally, this study presents academic and practical implications, as well as recommendations for future research.
\end{abstract}

Keywords: organizational culture; competing values model; outsourcing; sustainable performance

\section{Introduction}

With the evolution of customer demand and the increase in the level of competition, companies have started to look for new ways and strategies to increase competitiveness in order to improve their capabilities and create added value for their products and services. One of the strategies adopted by organizations is outsourcing in a pressured attempt to reach a competitive advantage, as it is recognized as a plausible strategic decision for certain functions [1].The hotel sector is characterized by having a variety of outsourced activities due to the complexity of performing them all with a high level of quality and efficiency [2].

Hotels began to adopt these strategies in order to outsource their secondary activities, focus on their core competencies and capabilities [3], and cope with globalization and the competitive environment [4]. According to Espino-Rodríguez and Padrón-Robaina [4], hotels outsource some activities, such as leisure activities, gardening, laundry, security and surveillance, information systems, and cleaning. Other activities are also outsourced, such as public relations, entertainment and business centers [5], transport services, and staff training [6]. Outsourcing corresponds to a structural decision of the hotel.

Hotel outsourcing can be defined as a management strategy where a hotel forms a strategic alliance with a supplier to carry out certain activities in the hotel in order to reduce costs and risks and improve 
efficiency [7]. According to Dorasamy et al. [8], several factors influence the adoption of outsourcing, such as the costs, the supplier's resources and capabilities, the risks, and the hotel's culture.

The organizational culture has become one of the most important factors to consider when planning and utilizing outsourcing strategies [9]. These strategies are developed according to the values and beliefs of the hotel, i.e., the organizational culture. Whenever any new managerial practices are implemented, it is necessary to comprehend its organizational culture in relation to its daily practices and its system of values and beliefs [10].

The literature has not produced a common definition of the concept of organizational culture, but rather various definitions depending on the study's approach. In the present study, a generic definition is used that describes culture as the pattern of values and beliefs shared by the members of an organization [11]. Organizational culture is a valuable factor in hotel policy, and it plays an important role in employee behavior and organizational outcomes. In addition, it is important to understand the role played by culture in outsourcing. Sometimes outsourcing forces hotels to change some values and beliefs in order to accept external suppliers [12]. This cultural adaptation may require the hotel to make changes in its policies and objectives.

Therefore, suppliers must understand and adapt to the hotel's organizational culture in order to create an appropriate atmosphere within the hotel, reap the benefits of outsourcing, and achieve the hotel's objectives [9]. Otherwise, a cultural disintegration could take place between the organization and the outsourcing companies [13].

The organizational culture influences the activities and behaviors of the staff of outsourcing companies when trying to achieve their goals [14]. The culture can have an important effect on organizational performance in areas such as sustainability and the outsourcing strategy. To date, these aspects have not been studied in the academic literature.

The tourism sector is currently experiencing a new environment in which customers increasingly demand to know the conditions of the products and services they are using. Furthermore, they want products and services produced in a sustainable and environmentally friendly way [15]. Therefore, hotels must adapt to this new reality by looking for new strategies where the sustainability factor is the basic principle [16]. Therefore, it is important to know whether outsourcing influences the sustainable performance of a hotel. This aspect has not been considered in previous research either.

In this regard, hotels should adopt sustainability strategies, not only to meet the needs of their customers, but also to fulfill the expectations of other stakeholders, such as individuals, partners, and governmental and non-governmental organizations $[17,18]$, in order to give added value to their products or services and gain competitive advantages. Therefore, hotels have to understand their customers' needs and stakeholders' expectations in designing outsourcing strategies that allow greater sustainability.

In fact, many companies have introduced or changed policies, processes, products, or services as a way to improve their relationship with the environment and become more sustainable [19]. However, various researchers suggest that these changes are superficial and insufficient, and that significant transformations must be made in the company's organizational culture $[20,21]$. In this context, the impact of the organizational culture on sustainable performance emerges. For Ibarra-Michel et al. [22], sustainability is considered a particular type of organizational culture. The cultural changes stemming from the adoption of sustainability strategies are reflected in the acceptance of certain new values and beliefs that respect the environment and are concerned with social and ethical issues. In this regard, several researchers suggest that sustainable performance is not only a humanistic, ethical, and conscientious issue, but it also produces economic effects for the company by improving its organizational performance and increasing its competitiveness [23-26]. The companies presenting a high sustainability performance show a specific organizational culture [27]. The sorts of cultures prove different impacts in performance [28,29].

A review of the existing literature shows that no studies have analyzed the impact of the organizational culture on outsourcing and sustainable performance worldwide. Based on the above, 
the present study aims to fill this gap in the academic literature and contribute some theoretical and practical implications to the literature in general and to the Egyptian hotel sector in particular.

The general objective of this study is to provide a structural model that analyzes the impact of the organizational culture on the level of outsourcing and sustainable performance. To achieve this objective, we used the CompetingValues Framework of organizational culture (CVF) [30]. The CVF was chosen because it has been validated in previous studies and research related to organizational culture, operations management, and sustainability [22,31-33].

\section{Conceptual Framework and Proposed Hypotheses}

\subsection{Organizational Culture}

In the late 1960s and early 1970s, there was a great deal of discussion about organizational theories on finding the best way to manage organizations. According to Sousa and Voss [34], organizational effectiveness was dependent on several factors: the size of the organization, the structure, and the age. In the 1980s, the cultural factor was added [35].

In this context, the concept of organizational culture emerged. This term first appeared in the literature in an article published in Pettigrew's Administrative Science Quarterly [36]. From that time on, culture was progressively mentioned in the field of organizations [37]. Over time, organizational culture has become a topic of considerable academic debate and an important theoretical factor in organizational theory [38]. However, we still have not had a consistent and common definition of organizational culture in the literature $[39,40]$. This variability in the definitions is due to researchers' perspectives, the issues being addressed, or different sets of values [41]. Most of these definitions of organizational culture highlight shared values within an organization.

Hofstede's [42] definition of culture indicates that it can be considered the collective mental programming that differentiates members of one group or category of people from others. Therefore, culture is an explanatory variable that distinguishes one organization from another $[43,44]$. Deal and Kennedy's [45] approach focuses on the proposed values, and they define culture as the published principles and values the organization's members aim to achieve, such as product quality or price leadership. Schein [46] defines it as "a pattern of basic assumptions invented, discovered, or developed by a group to face its problems of external adaptation and internal integration that it has considered valid and sufficient to be taught to new members as the right way to perceive, think, and feel in relation to those problems" (p. 17). Barney [47] defined it as "a complex set of values, beliefs, assumptions, and symbols that define the way an organization does business" (p. 656). Finally, the definitions of O'Reilly [48] and Chatman and Jehn [49] indicate that organizational culture is a set of widely shared and strongly held values.

Schein [46] proposed a three-level culture framework that interrelates and shapes the basic values and assumptions of organizational culture. The three levels are: the "productions" level, which represents people's beliefs about human behavior and reality; the "values" level, which represents the way people should relate and why they behave the way they do; the third level, "basic underlying assumptions", which represents the most visible cultural reactions, such as the ways individuals express what happens to them and how they solve their problems. These three levels have helped us to have a qualitative description of organizational culture. Organizational culture assists giving shape to strategies which firms employ for the acquisition of competitive advantages [50,51].

To empirically assess organizational culture, we use Quinn and Spreitzer's [52] Competing Values Framework (CVF), the most widely used model in empirical studies [31,53,54]. It has a strong theoretical basis [55] and uses short, valid instruments to measure organizational culture [56,57]. The CVF explores the basic assumptions and deep structures of organizational culture related to compliance with norms, motives, leadership, decision-making processes, effectiveness, values, and forms of organization in the company [58].

The CVF is based on two dimensions (control-flexibility and internal-external) [30,58,59] that reflect different value orientations [60]. The control-flexibility dimension (vertical axis) refers to the 
extent to which an organization can focus on stability in the presence of change. The flexibility approach reflects the organization's openness to spontaneity and stimulation, whereas the control approach indicates the company's ability to keep everything stable and under control. The internal-external dimension (horizontal axis) indicates the organization's orientation toward its internal environment versus the external world. On the one hand, the internal approach reflects the organization's ability to maintain and improve its existing capabilities; the external approach, on the other hand, refers to the organization's emphasis on competence, adaptation, and interaction with the outside world $[56,59,60]$ (see Figure 1).

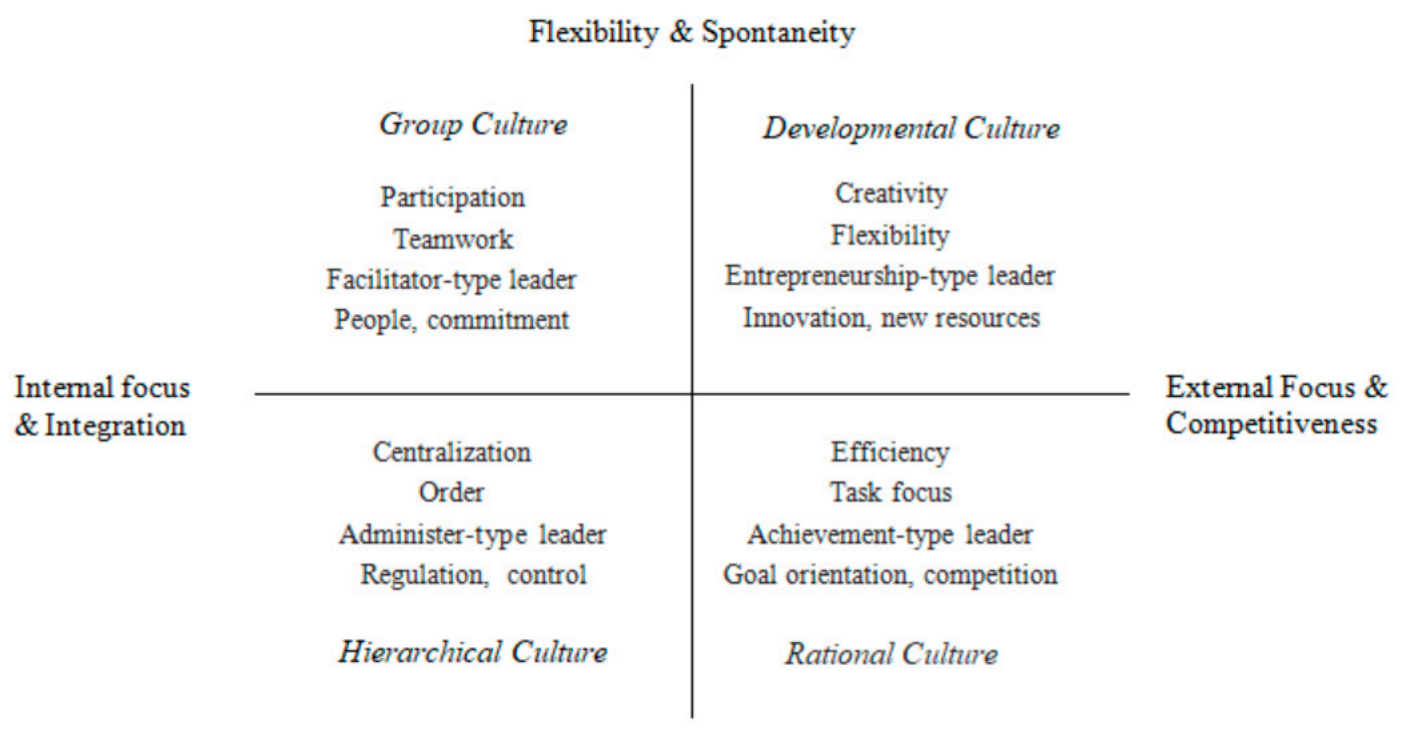

Control \& Stability

Figure 1. Competing values framework of organizational culture.

Based on the CVF, Quinn and Spreitzer [52] divided organizational culture into four typologies: hierarchical culture, group culture, development culture, and rational culture. The hierarchical culture focuses on stability and internal organization by emphasizing centralization and regulation with rules and the development of routines. The group culture focuses on flexibility and the internal approach by emphasizing human relations, cohesion, and the members' participation. The development culture emphasizes flexibility and external positioning through growth, resource acquisition, creativity, and adaptation to the outside world. The rational culture focuses on the external environment, with an emphasis on control by promoting competition and the achievement of well-defined objectives $[59,60]$. Organizations rarely reflect one type of culture; instead, they will have a combination of different types of culture, although one may dominate over the others [55]. A number of empirical studies have adopted the CVF to explore the effect of organizational culture on various operations management practices, such as technology, performance, quality management, and six sigma practices $[31,55,60]$.

The competing values framework of organizational culture of Denison and Spreitzer [59] adapted by $\mathrm{Zu}$ et al. [55].

\subsection{The Research Hypotheses}

\subsubsection{Hierarchical Culture}

The hierarchical culture is based on rules designed to maintain stability and control within the organization. This helps to establish a strict and formal organizational environment, where all employee behaviors are controlled by the rules and procedures that govern the company [61].

In addition, the hierarchical culture determines the operational processes and routines, and it specifies the authority structures for decisionmaking, which means that employees cannot make 
decisions without first receiving approval from their supervisors. Thus, in a hotel with a strong hierarchical culture, decisions are made from the top down.

For Braunscheidel et al. [62] and Ruppel and Harrington [63], the hierarchical culture has the disadvantage that employees are only accustomed to following the rules established in the company. Therefore, they may be reluctant to adapt to changes resulting from outsourcing, especially if the employees are transferred to the company providing the service. Hence, the hierarchical culture can negatively affect outsourcing because, in this culture, there is no incentive to participate in providing solutions to problems or acting in a more flexible way. The outsourcing strategy involves delegating the development of activities to external suppliers, so that hotels can lose control of activities, which can increase the hotel's dependence [64]. Outsourcing involves leaving activities in the hands of external suppliers, which means that some rules are imposed by the suppliers. In addition, managers might be afraid that suppliers will not comply with the promised quality and/or quantity [65], which may produce instability, an aspect that is incompatible with this type of culture. Therefore, this culture based on centralization and regulation makes it difficult to use outsourcing strategies successfully. Thus, the following hypothesis is proposed:

Hypothesis 1 (H1a). The hierarchical culture negatively influences the outsourcing level.

With regard to sustainability, according to Cameron and Quinn [61] and Griffiths and Petrick [66], this culture has an internal approach focused on economic results and process control, rather than on the organization's concerns about the external environment and environmental and social performance. Therefore, this culture based on formalization restricts the implementation and understanding of sustainability [67]. In this regard, this economic sustainability based on reducing costs and maximizing profits is not sufficient to achieve sustainable performance and concern for environmental and social systems [68].

In addition, according to Senge et al. [69], companies oriented only toward economic results could miss out on the innovations of sustainable performance and the business opportunities that sustainability provides. According to Dunphy et al. [17], it is difficult to adopt innovative products, services, and strategies, as well as sustainable performance, without the presence of learning spaces and flexibility within an organization, which are not found in the hierarchical culture. Thus, this culture of centralization and regulation greatly limits sustainable performance [66].

Therefore, hotels that emphasize a hierarchical culture while seeking to implement sustainability strategies could experience strong cultural shock and tension because their existing culture is based on control and stability, and sustainable performance requires flexibility and exploration [22,69].Hence, the following hypothesis is proposed:

Hypothesis 1 (H1b). The hierarchical culture negatively influences sustainable performance.

\subsubsection{Group Culture}

The group culture is characterized by the participation of the members of the organization, teamwork, and an increase in the employees' level of knowledge [61]. Furthermore, in this culture, the strategies emphasize human relations within the company by strengthening mutual trust between employees or between the employees and the company, sharing information and knowledge and exchanging experiences [70]. This makes it possible to reduce conflicts within the organization, improving the quality of the services and achieving the company's objectives.

Despite these advantages of the group culture, employees of external suppliers may disrupt this culture, especially when there is no collaboration between internal and external employees due to the competition that may exist between them [12]. In this regard, as rumours of outsourcing agreements begin to circulate, managers can expect talented employees to start to look for jobs, and others may become anxious and lower their production [71]. Therefore, for some employees, outsourcing is viewed 
as possible job loss [72]. The results of the study by Elmuti et al. [73] indicate the negative influence of outsourcing strategies on the quality of working life.

Some authors, such as Domberger [74], Kakabads and Kakabadse [75], Belcourt [71], Geishecker [76] and Lamminmaki [2], suggest that outsourcing negatively affects the organization's internal employees because they feel insecure about losing their jobs. They fear that managers might think external suppliers are more competent and efficient. Employee performance may decline, and some employees may suffer from a lack of motivation. From a group culture perspective, they are likely to feel that the suppliers are not members of the group, and so they may not have the spirit of cooperation and collaboration with external suppliers, withholding information that can have consequences due to not taking full advantage of the benefits of outsourcing. Kakabads and Kakabadse [75] and Lamminmaki [2] suggest that, when outsourcing is carried out, internal employees may be unable to establish links with external employees. Based on this reasoning, the following hypothesis is proposed:

Hypothesis 2 (H2a). The group culture negatively influences the outsourcing level.

Organizations that are oriented towards this cultural approach pay a lot of attention to employee training, learning, and internal development of the staff's skills and capabilities for operative and sustainable performance [17]. This suggests that these employees or managers would show a strong tendency towards non-economic interests, such as human relations, human wellbeing, and environmental and social performance [77]. Therefore, this culture would emphasize individuals' participation in their surroundings and the increase in knowledge about their work and environment. These are the basic pillars for creating a sustainability-oriented culture [17]. For these reasons, the following hypothesis is proposed:

Hypothesis 2 (H2b). The group culture positively influences sustainable performance.

\subsubsection{Rational Culture}

The rational culture, which has an external focus, is oriented towards planning, the efficient use of resources, and competitiveness, as well as achieving the organizational objectives while emphasizing control and stability [41]. Therefore, organizations that emphasize this type of culture are quite demanding. They aim to achieve competitiveness and competitive advantage by developing clear objectives and strategies that contribute to increasing productivity and profitability [59]. In addition, a rational culture is characterized by using incentives as a tool to motivate employees to perform their tasks to the best of their ability and improve their outcomes.

In this context, hotels that are oriented towards a rational culture seek cooperation and integration with their customers and suppliers in order to be more competitive. This type of culture facilitates a close relationship with external customers and suppliers. External suppliers strive to satisfy the needs of their customers, and they will allow the organization to achieve better results, create competitive advantages, and improve operational efficiency and productivity [78-80]. Therefore, in a rational culture where the organization's objectives are predetermined and clear, external suppliers with higher capabilities than those of the client (e.g., the hotel) can perform certain activities efficiently based on the organization's objectives and strategic plans $[59,80]$. Strategic outsourcing decisions are rational, and decision making is analyzed in a rational way, with the whole organization involved in planning the services to be outsourced [3]. This type of culture can favor a strategy where activities that are not basic to the hotel are outsourced to improve productivity and profitability. Therefore, the following hypothesis is proposed:

Hypothesis 3 (H3a). The rational culture positively influences the outsourcing level.

In the case of sustainability, the rational culture is characterized by constantly searching for efficiency in the resources used and planning and adapting organizational strategies that favor 
sustainability. Sustainable performance plays an important role in improving quality in all the processes and products, which helps organizations to be more competitive and efficient and present a positive image to their current and future customers [17]. This efficiency should not only focus on reducing costs and simplifying products, but also on the environment and society. Efficiency based on economic results is not sufficient to achieve sustainable performance. Furthermore, it only provides the hotel with a short-term competitive advantage that can easily be copied by competitors [32]. Instead, this new efficiency approach based on sustainable performance offers hotels real long-term advantages, reducing costs and ecological impacts, improving their reputation, and increasing organizational results. These cost savings can be harnessed for other tasks, such as training employees in sustainable performance or innovation in other areas. Therefore, the objectives of the rational culture can be compatible with more sustainable performance. For these reasons, the following hypothesis is proposed:

Hypothesis 3 (H3b). The rational culture positively influences sustainable performance.

\subsubsection{Development Culture}

The development culture emphasizes the importance of the external environment for flexibility in the structure, learning, and changes in the life of the company [41]. This culture is geared towards achieving long-term goals through the use of strategies such as innovation, the acquisition of new resources, and the creation of new markets and challenges. The development culture emphasizes quality, employee commitment, recognition of the social environment, and external integration of customers and other stakeholders [81]. These strategies allow companies to be more flexible and dynamic and adapt quickly to changing demands and customer needs.

Therefore, the participation of external suppliers and the functions of external organizations are increasingly essential in hotels because they cannot develop all their capacities internally [64]. External suppliers provide companies with reliable information about products, markets, resources, and the necessary technologies to carry out their activities, as well as the best capabilities and skills [82]. Strategic alliances and agreements with suppliers allow organizations to obtain specialized skills and optimize their chances to improve service quality, achieve competitive advantages, and face new challenges [83]. Hotels reach these agreements with suppliers to acquire new resources, which favors greater flexibility in the management of the production process of a hotel. Flexibility and resource acquisition are key aspects of the development culture. Outsourcing implies the acquisition of resources and close relationships with external suppliers, which facilitates the adaptation to the environment required by the development culture [52,60]. Therefore, the following hypothesis is proposed:

Hypothesis 4 (H4a). The development culture positively influences the outsourcing level.

The development culture can be classified as an open culture, which means that it emphasizes innovation and flexibility to achieve successful sustainable performance (environmental and social). With regard to environmental performance, companies that follow a strong orientation towards the development culture feel that they are not separate from their environmental surroundings and show concern about environmental issues [84]. These hotels have a real challenge in dedicating their resources and processes to strategies and behaviors that respect the environment. In terms of social performance, these hotels try to be proactive with the world around them, such as stakeholders and communities. Therefore, they take a keen interest in social issues such as community wellbeing, stakeholder needs, and minorities' concerns [85]. Thus, organizations that are oriented toward the development culture are aware of the surrounding external environment and socio-economic issues [32], in an attempt to understand and adapt to change. In this context, the results of Sugita and Takahashi's [86] study with 109 Japanese companies show that companies that emphasize the development culture are more successful with sustainability strategies. For this reason, the following hypothesis is formulated:

Hypothesis 4 (H4b). The development culture positively influences sustainable performance. 


\subsubsection{Outsourcing Level and Sustainable Performance}

According to Hart and Dowell [87], the incorporation of external companies in operational activities allows the organization to have more access to the voice of the external environment and seek more sustainability-oriented strategies. In this way, it improves the organization's internal knowledge resources and reduces the technological and marketing uncertainties that arise from these strategies [88]. An increase in outsourcing allows hotels to focus on their core competencies, obtain lower costs, and increase productivity. Consequently, the business can focus on aspects related to improving sustainability and better respond to demands for social responsibility and ecological concern. Outsourcing could improve aspects related to financial performance and social and environmental issues, raising the expectations of the stakeholders. Companies can become more sustainable in the long term and much more efficient from a global perspective [89]. Outsourcing can encourage the hotel to focus on developing the most sustainable processes by leaving its non-core activities in the hands of external suppliers. Outsourcing can allow the hotel to devote more resources and time to focusing on aspects that contribute to improving sustainability. Therefore, the knowledge gained through outsourcing not only helps the organization to cover its operational needs, but also the environmental and social demands during the development and production of sustainable products and services [90]. The practice of outsourcing can enable improvements in firm processes throughout the elimination of inefficient operations [91].Furthermore, it allows companies to understand and incorporate the implications that arise from the use of sustainable solutions, such as changes in consumption patterns or product life cycles [33]. In this context, outsourcing can positively influence the sustainable performance of an organization.

Therefore, we propose the following hypothesis:

Hypothesis 5 (H5). The outsourcing level has a positive impact on sustainable performance.

The proposed hypotheses suggest the model shown in Figure 2.

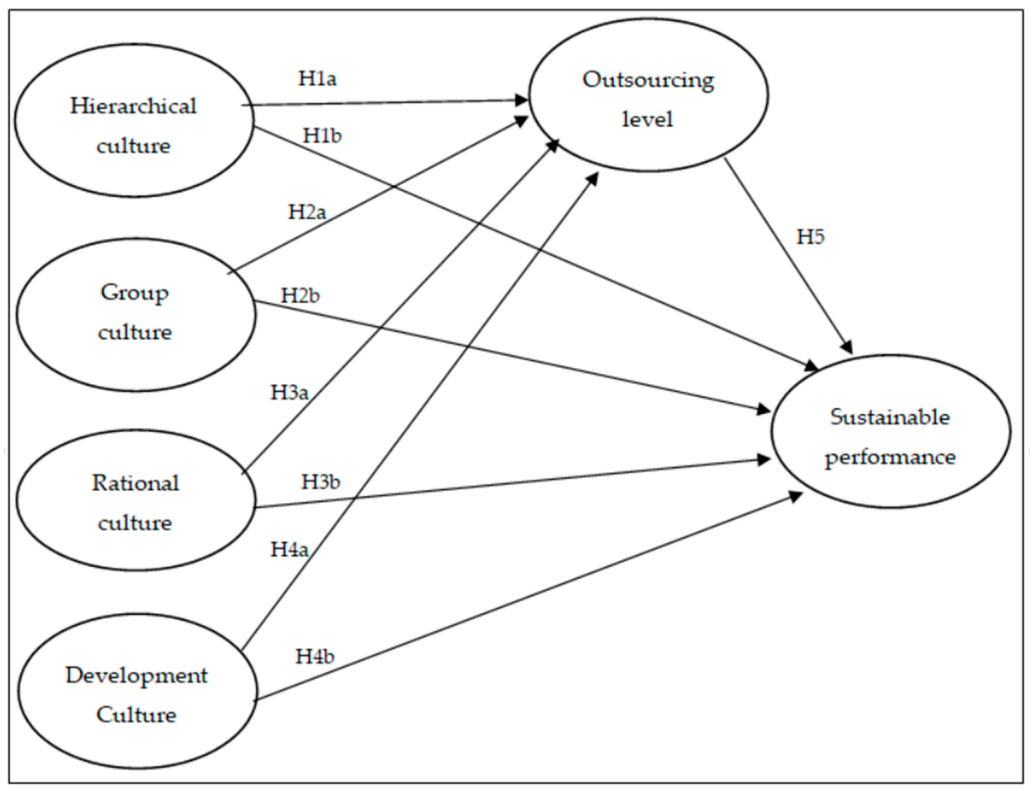

Figure 2. Conceptual model and hypotheses.

\section{Methodology}

\subsection{Study Setting and Sample}

The setting for our research was the tourist destination of Egypt. Egypt is considered one of the most important tourist destinations in the world due to the competitive advantages of its different 
types of tourism. A total of 13.6 million foreigners visited Egypt in 2019, with an income of 13 billion dollars, which represents an increase of almost $12 \%$ compared to the previous year [92].

Within this broad destination, two tourist cities, Sharm El Sheikh and Hurgada, were selected. These two cities were selected because, along with Cairo, they are the most popular tourist destinations in Egypt, and they have the bulk of the accommodation offer. They have a wide variety of hotels with different characteristics, and so they are considered an ideal population for our study.

In addition, these two cities are considered a consolidated segment of sun and beach tourism, as well as sport and conference tourism. These destinations have a diversified tourist offer with signs of maturity and greater competitiveness due to the appearance of new destinations and tourism products.

After determining the geographical area for the research, we chose the unit of analysis; therefore, we decided to focus on 4- and 5-star sun and beach hotels in the cities of Sharm El Sheikh and Hurgada. A list of the 4- and 5-star establishments in Sharm El Sheikh and Hurgada was prepared containing their data, including name, address, category, and telephone number. This information was collected from the Egyptian Hotel Industry Association, which comprises149 registered establishments.

The distribution of these establishments is as follows: Sharm El Sheikh has 93 hotels (51 5-star and 42 4-star establishments), and Hurgada has 56 hotels (25 5-star and 31 4-star establishments). A structured questionnaire was developed to obtain the research data. The survey was carried out personally by the researcher in order to obtain a higher response rate.

First, we contacted the directors of the tourism offices dependent on the Ministry of Tourism in these two cities to help us arrange appointments with the hotels. These directors and colleagues contacted the hotels to make an appointment with each of them. In addition, some hotel directors or managers helped us to contact people from other hotels so that they could participate in the research.

Of the entire study population of 149 hotels, 114 hotels participated in the study. This means that we obtained an actual response rate of $76.5 \%$, the majority of the hotels in the two cities, and so the representativeness of the sample was high. In the city of Sharm El Sheikh, the sample consisted of 72 hotels, whereas, in the city of Hurgada, 42 hotels participated in the survey. Finally, it should be noted that, of the hotels that participated in the sample, 33 of them belonged to international chains.

\subsection{Measurement of the Variables}

Based on the review of the theoretical and empirical literature on outsourcing, organizational culture, and sustainable performance, a questionnaire was created to achieve the proposed objectives of this research. Before collecting the data, the questionnaire was subjected to a pilot test. The pre-test was carried out by a group of two academics and two managers to validate the scales and clarify ambiguous expressions on the questionnaires.

To measure the chosen constructs, previously developed and validated scales were selected from the literature. Furthermore, in this research, a 7-point Likert-type scale is used, where 1 means strongly disagree and 7 means strongly agree. Respondents express the degree of agreement or disagreement with each item (See Appendix A).

Organizational culture. Although different cultural typologies have been proposed, Quinn and Spreitzer's [52] cultural typology is the one most widely used in empirical studies because it has a solid theoretical base in the Competing Values Framework (CVF) and rather short and validated measurement scales for organizational culture. Therefore, in this study, we used the Quinn and Spreitzer [52] typology to measure organizational culture. Quinn and Spreitzer [52] divided organizational culture into four types: hierarchical, group, rational, and development cultures. The scales for the four types of organizational culture are taken from the work by Gambi et al. [93], and Prajogo and McDermott [31]. Each type of culture has five items (See Appendix A).

Hierarchical culture. This type of culture emphasizes order, stability, rules and regulations within the organization and internal efficiency, as ways to regulate the behavior of all employees. On this scale, we assess the degree of control in the hotel, the decision-making structure, and the aims of this 
culture. Each type of culture has been measured with a scale containing five statements to measure this type of culture (See Appendix A).

Group Culture. It is based on values such as teamwork, members' participation in the organization, and increasing the capacity and knowledge of the employees. Managers reinforce these values to create a perfect environment within the organization. On this scale, we measure the degree of communication among employees, participation in decisionmaking, and management's concern and support for human resource development.

Rational Culture. This culture focuses on production and achieving objectives and performing tasks, with the objectives representing a way of controlling employee behavior. It evaluates whether the hotel's objectives are clear, whether the incentives encourage the employees, and whether the hotel's strategies are oriented towards competitiveness.

Development Culture. The emphasis is on innovation, creativity, and adaptation for growth. Leadership supports companies and inspires creativity in employees with the hope of acquiring new resources for the organization. This scale measures the degree of the use of technology and innovation, the continuous search for new opportunities and markets, and the ability to take risks.

Outsourcing level. This scale focuses on measuring the total degree of outsourcing in the entire hotel, not in the activity. In this regard, we measure whether the hotel is highly outsourced or not, to what degree the departments are dependent on external companies, the volume of services the hotel has outsourced, and the percentage of external workers. In this study, a Likert-type scale ranging from 1 to 7 was used to rate five items [64]. (See Appendix A).

Sustainable performance. For Morelli [94], sustainability is considered a new type of organizational culture because hotels are forced to change certain values and adapt to a new setting where they focus the attention on the environment. Sustainable performance is measured with the scale used by [33]. The scale is composed of five items and measures questions about the extent to which the hotel responds to social and ethical demands, as well as the degree to which the hotel's reputation for sustainability is better than that of its competitors.

\section{Analysis and Results}

To test the research hypotheses, a structural equation model was carried out using the statistical program SmartPLS 3.2.8 [95]. Structural equation models allow researchers to statistically examine a series of dependent and interrelated relationships among theory-based constructs and their indicators, measured through directly observable variables [96].

The Partial least squares PLS technique is primarily used for the theoretical development of exploratory research [97], and it is currently considered the most widely used technique in social science studies and the best method for multivariate analysis [98]. PLS is a well-established structural equation analysis technique that is used in a variety of outsourcing studies $[64,99,100]$.

PLS is used when the theory is not solidly developed, as in the case of the relationship between organizational culture, outsourcing, and sustainable performance. This technique is less demanding about the minimum sample size requirements than other techniques such as Linear structural relations LISREL or Structural equation modeling EQS [101]. PLS does not require data to come from normal or known distributions, and it is more suitable for theories and research topics with few studies [98].

The process of analyzing a PLS model has two steps: the measurement model (Outer Models) and the structural model (Inner Models) [98]. The evaluation of the measurement model consists of analyzing the reliability level of the observed variable in the model and in each construct, as well as the convergent and discriminant validity [102]. The structural model compares the hypotheses and analyzes the predictive capacity of the proposed model [103].

\subsection{Measurement Model}

In order to evaluate the measurement model designed to assess the relationships between each construct and its indicators in PLS, an analysis is performed on the variables in the model with regard 
to (i) individual reliability coefficients for the indicator and the construct; (ii) convergent validity; and (iii) discriminant validity $[98,102,104,105]$.

On the one hand, to analyze the reliability of each indicator in the measurement model, the factor loadings of the items on their respective constructs were evaluated. Carmines and Zeller [106] suggested that the individual reliability of an item is considered adequate when it exceeds the recommended threshold of 0.707. However, Tenenhaus et al. [105] observe that a loading level equal to or greater than 0.7 may be too rigid. Therefore, they suggested that items are acceptable when they exceed the threshold of 0.5 . Items with values below 0.50 were eliminated. In our study, the results show that all the factor loadings exceed 0.6, suggesting acceptable individual reliability. Table 1 shows that the factor loadings range from 0.614 to 0.976 .

Table 1. Evaluation of the measurement model. Reliability and construct validity.

\begin{tabular}{|c|c|c|c|c|c|c|}
\hline & Indicators & $\begin{array}{c}\text { Factor } \\
\text { Loading }\end{array}$ & $\mathbf{T}$ & CR & $\begin{array}{l}\text { Composite } \\
\text { Reliability }\end{array}$ & AVE \\
\hline \multirow{3}{*}{$\begin{array}{l}\text { Hierarchical } \\
\text { Culture }\end{array}$} & HC_1 & 0.797 & 19.560 & \multirow{3}{*}{0.765} & \multirow{3}{*}{0.864} & \multirow{3}{*}{0.679} \\
\hline & HC_2 & 0.973 & 21.283 & & & \\
\hline & HC_3 & 0.880 & 46.738 & & & \\
\hline \multirow{4}{*}{$\begin{array}{l}\text { Group } \\
\text { Culture }\end{array}$} & GC_1 & 0.792 & 23.088 & \multirow{4}{*}{0.847} & \multirow{4}{*}{0.897} & \multirow{4}{*}{0.685} \\
\hline & GC_2 & 0.814 & 23.073 & & & \\
\hline & GC_3 & 0.872 & 36.163 & & & \\
\hline & GC_4 & 0.832 & 25.731 & & & \\
\hline \multirow{5}{*}{$\begin{array}{l}\text { Rational } \\
\text { Culture }\end{array}$} & RC_1 & 0.726 & 15.166 & \multirow{5}{*}{0.859} & \multirow{5}{*}{0.899} & \multirow{5}{*}{0.643} \\
\hline & RC_2 & 0.693 & 13.246 & & & \\
\hline & RC_3 & 0.900 & 56.806 & & & \\
\hline & RC_4 & 0.819 & 30.037 & & & \\
\hline & RC_5 & 0.852 & 25.860 & & & \\
\hline \multirow{5}{*}{$\begin{array}{l}\text { Development } \\
\text { Culture }\end{array}$} & DC_1 & 0.850 & 39.587 & \multirow{5}{*}{0.907} & \multirow{5}{*}{0.931} & \multirow{5}{*}{0.730} \\
\hline & DC_2 & 0.778 & 20.679 & & & \\
\hline & DC_3 & 0.886 & 50.276 & & & \\
\hline & DC_4 & 0.885 & 46.184 & & & \\
\hline & DC_5 & 0.870 & 42.300 & & & \\
\hline \multirow{5}{*}{$\begin{array}{c}\text { Outsourcing } \\
\text { level }\end{array}$} & OL_1 & 0.908 & 38.690 & \multirow{5}{*}{0.913} & \multirow{5}{*}{0.937} & \multirow{5}{*}{0.752} \\
\hline & OL_2 & 0.918 & 84.553 & & & \\
\hline & OL_3 & 0.932 & 104.716 & & & \\
\hline & OL_4 & 0.920 & 57.570 & & & \\
\hline & OL_5 & 0.614 & 8.654 & & & \\
\hline \multirow{5}{*}{$\begin{array}{l}\text { Sustainable } \\
\text { performance }\end{array}$} & SP_1 & 0.937 & 106.948 & \multirow{5}{*}{0.968} & \multirow{5}{*}{0.975} & \multirow{5}{*}{0.888} \\
\hline & SP_2 & 0.976 & 236.050 & & & \\
\hline & SP_3 & 0.910 & 72.106 & & & \\
\hline & SP_4 & 0.975 & 225.182 & & & \\
\hline & SP_5 & 0.913 & 58.002 & & & \\
\hline
\end{tabular}

On the other hand, Cronbach's alpha and composite reliability (CR) are used to evaluate the reliability of the constructs. The recommended value for Cronbach's alpha and the composite reliability of the constructs should be above 0.7 [104]. The results in Table 1 indicate that all the latent variables 
are reliable because the composite reliability values exceed the threshold of 0.7 , ranging between 0.864 and 0.975 . In addition, the Cronbach's alpha value for each construct exceeds the recommended threshold of 0.7 , ranging from 0.765 to 0.968 . Therefore, the reliabilities of the latent variables in our study exceed the necessary thresholds [96].

Convergent validity is measured with the average variance extracted (AVE) from each construct, which refers to the mean variance shared by the latent variable and its items. The recommended AVE value is equal to or greater than $0.5[98,104]$. Table 1 shows that the AVE values exceed the threshold of 0.5 , ranging from 0.643 to 0.888 , thus confirming convergent validity.

Discriminant validity refers to whether the measure of a construct is empirically different from the other constructs in the same model [107]. To evaluate discriminant validity, theFornell-Larcker criterion, the cross-loadings, and the Heterotrait-MonotraitRatio (HTMT) correlations are used [108].

Fornell and Larcker [104] indicate that, for discriminant validity to exist, the square root of the AVE values must be greater than all the correlations between all the constructs in the same model. Table 2 shows that, in all cases, the square root of the AVE (main diagonal) is higher than the correlations between the constructs. The results of this analysis suggest that all the constructs are unique concepts.

Table 2. Discriminant validity and theFornell-Larckercriterion.

\begin{tabular}{ccccccc}
\hline Variables & HC & GC & RC & DC & OL & SP \\
\hline Hierarchical culture & 0.824 & & & & & \\
\hline Group culture & 0.712 & 0.828 & & & & \\
\hline Rational culture & 0.726 & 0.789 & 0.802 & & & \\
\hline Development culture & 0.751 & 0.812 & 0.792 & 0.855 & & \\
\hline Outsourcing level & -0.604 & -0.562 & -0.603 & -0.624 & 0.867 & \\
\hline Sustainable performance & 0.746 & 0.734 & 0.742 & 0.779 & -0.614 & 0.942 \\
\hline
\end{tabular}

Factor cross-loadings. According to this criterion, the cross-loadings for the observed variables in a construct are compared to the loadings for the observed variables in the other constructs. The value of the cross-loadings for a latent variable has to be greater than the values for the other variables in the same model [103]. Table 3 shows that the loadings are higher in their respective constructs than in the other constructs, providing evidence of the discriminant validity of the constructs [98]. Therefore, these results suggest that there is discriminant validity.

Table 3. Cross-loadings.

\begin{tabular}{ccccccc}
\hline Variables & HC & GC & RC & DC & OL & SP \\
\hline HC_1 & 0.797 & 0.558 & 0.555 & 0.626 & -0.431 & 0.529 \\
\hline HC_2 & 0.793 & 0.540 & 0.574 & 0.553 & -0.513 & 0.522 \\
\hline HC_3 & 0.880 & 0.653 & 0.658 & 0.674 & -0.542 & 0.759 \\
\hline GC_1 & 0.530 & 0.792 & 0.594 & 0.625 & -0.326 & 0.575 \\
\hline GC_2 & 0.618 & 0.814 & 0.653 & 0.652 & -0.473 & 0.611 \\
\hline GC_3 & 0.642 & 0.872 & 0.667 & 0.720 & -0.520 & 0.657 \\
\hline GC_4 & 0.560 & 0.832 & 0.694 & 0.686 & -0.519 & 0.585 \\
\hline RC_1 & 0.509 & 0.545 & 0.726 & 0.560 & -0.420 & 0.509 \\
\hline RC_2 & 0.467 & 0.445 & 0.693 & 0.477 & -0.408 & 0.463 \\
\hline RC_3 & 0.643 & 0.774 & 0.900 & 0.758 & -0.546 & 0.693 \\
\hline
\end{tabular}


Table 3. Cont.

\begin{tabular}{ccccccc}
\hline Variables & HC & GC & RC & DC & OL & SP \\
\hline RC_4 & 0.656 & 0.616 & 0.819 & 0.639 & -0.526 & 0.629 \\
\hline RC_5 & 0.610 & 0.732 & 0.852 & 0.702 & -0.500 & 0.647 \\
\hline DC_1 & 0.665 & 0.772 & 0.739 & 0.850 & -0.518 & 0.716 \\
\hline DC_2 & 0.543 & 0.620 & 0.585 & 0.778 & -0.466 & 0.633 \\
\hline DC_3 & 0.647 & 0.697 & 0.672 & 0.886 & -0.579 & 0.665 \\
\hline DC_4 & 0.632 & 0.723 & 0.673 & 0.885 & -0.538 & 0.613 \\
\hline DC_5 & 0.709 & 0.652 & 0.705 & 0.870 & -0.560 & 0.694 \\
\hline OL_1 & -0.437 & -0.440 & -0.492 & -0.529 & 0.908 & -0.514 \\
\hline OL_2 & -0.617 & -0.586 & -0.632 & -0.628 & 0.918 & -0.630 \\
\hline OL_3 & -0.630 & -0.571 & -0.596 & -0.611 & 0.932 & -0.624 \\
\hline OL_4 & -0.451 & -0.449 & -0.505 & -0.522 & 0.920 & -0.496 \\
\hline OL_5 & -0.447 & -0.332 & -0.321 & -0.361 & 0.614 & -0.327 \\
\hline SP_1 & 0.746 & 0.624 & 0.680 & 0.722 & -0.584 & 0.937 \\
\hline SP_2 & 0.713 & 0.752 & 0.734 & 0.764 & -0.605 & 0.976 \\
\hline SP_3 & 0.664 & 0.695 & 0.683 & 0.733 & -0.610 & 0.910 \\
\hline SP_4 & 0.708 & 0.743 & 0.721 & 0.755 & -0.597 & 0.975 \\
\hline SP_5 & 0.684 & 0.641 & 0.677 & 0.694 & -0.494 & 0.913 \\
\hline
\end{tabular}

The Heterotrait-Monotrait Ratio correlations. The Heterotrait-Monotrait Ratio (HTMT) inference test was used to determine whether the HTMT values were significantly less than one [109]. The 95\% confidence intervals of the HTMT values were calculated using the bootstrapping procedure in SmartPLS. Table 4 shows the lower and upper limits of the confidence intervals. None of them includes the value of one, and so there is discriminant validity for all the constructs [108].

Table 4. Discriminant validity: Heterotrait-Monotrait Ratio (HTMT) of 5\% and 95\%. Confidence Intervals.

\begin{tabular}{|c|c|c|c|c|c|c|}
\hline Variables & $\mathrm{HC}$ & GC & RC & DC & LO & SP \\
\hline Hierarchical culture & - & & & & & \\
\hline Group culture & $(0.622 ; 0.785)$ & - & & & & \\
\hline Rational culture & $(0.661 ; 0.786)$ & $(0.736 ; 0.839)$ & - & & & \\
\hline Development culture & $(0.679 ; 0.816)$ & $(0.764 ; 0.854)$ & $(0.734 ; 0.845)$ & - & & \\
\hline Outsourcing level & $(0.671 ; 0.810)$ & $(-0.648 ;-0.470)$ & $(-0.693 ;-0.502)$ & $(-0.711 ;-0.537)$ & - & \\
\hline Sustainable performance & $(-0.702 ;-0.492)$ & $(0.669 ; 0.794)$ & $(0.672 ; 0.804)$ & $(0.712 ; 0.840)$ & $(-0.697 ;-0.524)$ & - \\
\hline
\end{tabular}

\subsection{Structural Model}

After establishing and confirming the reliability and validity of the measurement model, hypothetical relationships and structural model results were evaluated. This process is based on observing the relevance and predictive capacity of the model and the relationships between endogenous constructs [98].

The evaluation of the structural model involves examining the explained variance $\left(R^{2}\right)$, the standardized path coefficients $(\beta)$, the statistical $t$ value, the effect size $\left(\mathrm{f}^{2}\right)$, the predictive relevance of the model (the Stone-Geisser test $\mathrm{Q}^{2}$ ), and the goodness-of-fit index (GOF).

Following Hair et al. [98], the non-parametric Bootstrap test with 500 repetitions was performed to obtain the explained variance $\left(R^{2}\right)$, the $f^{2}$ effect, and the standardized Path coefficients $(\beta)$ for each of the predicted relationships in the hypotheses of the model, with the observed $t$ values. First, the fit 
of the structural model was confirmed with the $\mathrm{R}^{2}$, which represents the explained variance of the dependent variables. For Falk and Miller [110], these values should be higher than the threshold of 0.1, which means $10 \%$, in order for the model to have a predictive capacity. As Table 5 shows, the dependent construct that measures sustainable performance presents an $R^{2}$ of 0.696 , which means that $69.6 \%$ of the variability in sustainable performance is explained by the organizational culture and by the level of outsourcing. In contrast, $44.6 \%\left(R^{2}=0.446\right)$ of the variability in the outsourcing level is explained by the organizational culture. This suggests that the model has a predictive capacity (see Table 5).

Table 5. Goodness-of-fit (GoF) (index).

\begin{tabular}{clll}
\hline Variables & AVE & $\mathbf{R}^{2}$ & $\mathbf{Q}^{2}$ \\
\hline Hierarchical culture & 0.679 & & \\
\hline Group culture & 0.685 & & \\
\hline Rational culture & 0.643 & & \\
\hline Development culture & 0.730 & & 0.303 \\
\hline Outsourcing level & 0.752 & 0.446 & 0.574 \\
\hline Sustainable performance & 0.888 & 0.696 & \\
\hline AVE $\times \mathrm{R}^{2}$ & & 0.416 & \\
\hline GoF $=\sqrt{\mathrm{AVE}} \times \mathrm{R}^{2}$ & & 0.645 & \\
\hline
\end{tabular}

In relation to the predictive relevance of the model, which is calculated through the $\mathrm{Q}^{2}$ value, we employed the Stone-Geisser $Q^{2}$ test $[111,112]$, a technique used to measure the predictive relevance of independent constructs [108]. According to the Stone-Geisser test, a model can have predictive relevance when the $\mathrm{Q}^{2}$ values are greater than zero [98]. Table 5 shows that all the $\mathrm{Q}^{2}$ values are above the threshold limit (the level of Outsourcing, 0.303, and the level of sustainable performance, 0.574 ), and so the model has predictive relevance.

For the goodness of fit, Tenenhaus et al. [105] propose using a global criterion for model validation. Specifically, we use the Goodness-of-fit (GOF) indicator, which consists of calculating the geometric mean of the average communality (AVE) by the average $R^{2}$. According to Chin [113], models that reach a value of more than 0.36 are considered good-fitting models. In this case, the value is 0.645 (see Table 5), and so we can state that the model has sufficient predictive quality.

The $\mathrm{f}^{2}$ effect size measures the impact of each exogenous (independent) latent variable on the endogenous (dependent) latent variable. This effect measures whether removing an independent variable from the model changes the value of the determination coefficient, and it defines whether the exogenous variable removed has a significant influence on the value of the endogenous variables. Based on Cohen [114], the $\mathrm{f}^{2}$ values have to be above the recommended threshold of 0.02 . As Table 6 shows, most of the $f^{2}$ effects obtained from the significant variables that explain the variability in the dependent variables are higher than the base level of 0.02 .

The standardized path coefficients are shown in Table 6 and Figure 3. With regard to hypothesis $\mathrm{H} 1 \mathrm{a}$, the results show that a hierarchical culture has a negative influence on the level of outsourcing ( $\beta=-0.249, p<0.05)$; therefore, this hypothesis is supported. In addition, hypothesis H1b, which predicted the negative impact of the hierarchical culture on sustainable performance, is found to have a significant impact, although the relationship is positive $(\beta=0.254, p<0.01)$, contrary to the prediction. Therefore, hypothesis $\mathrm{H} 1 \mathrm{~b}$ is rejected. 
Table 6. Path coefficients, t-statistics, and F-squared.

\begin{tabular}{cccccc}
\hline Hypothesis & $\boldsymbol{B}$ & $\mathbf{t}$ & $\boldsymbol{p}$ & $\mathbf{f}^{2}$ & Conclusion \\
\hline Hierarchical culture $\rightarrow$ Outsourcing level & -0.249 & 1.754 & 0.040 & 0.043 & Supported \\
\hline Hierarchical culture $\rightarrow$ Sustainable performance & 0.254 & 2.780 & 0.003 & 0.078 & NotSupported \\
\hline Group culture $\rightarrow$ Outsourcing level & 0.001 & 0.010 & 0.496 & 0.000 & NotSupported \\
\hline Group culture $\rightarrow$ Sustainable performance & 0.135 & 1.414 & 0.079 & 0.017 & Supported \\
\hline Rational culture $\rightarrow$ Outsourcing level & -0.205 & 1.440 & 0.075 & 0.022 & NotSupported \\
\hline Rational culture $\rightarrow$ Sustainable performance & 0.161 & 1.659 & 0.049 & 0.024 & Supported \\
\hline Development culture $\rightarrow$ Outsourcing level & -0.276 & 2.141 & 0.016 & 0.035 & NotSupported \\
\hline Development culture $\rightarrow$ Sustainable performance & 0.281 & 2.330 & 0.010 & 0.063 & Supported \\
\hline Outsourcing level $\rightarrow$ Sustainable performance & -0.112 & 1.656 & 0.049 & 0.023 & NotSupported \\
\hline
\end{tabular}

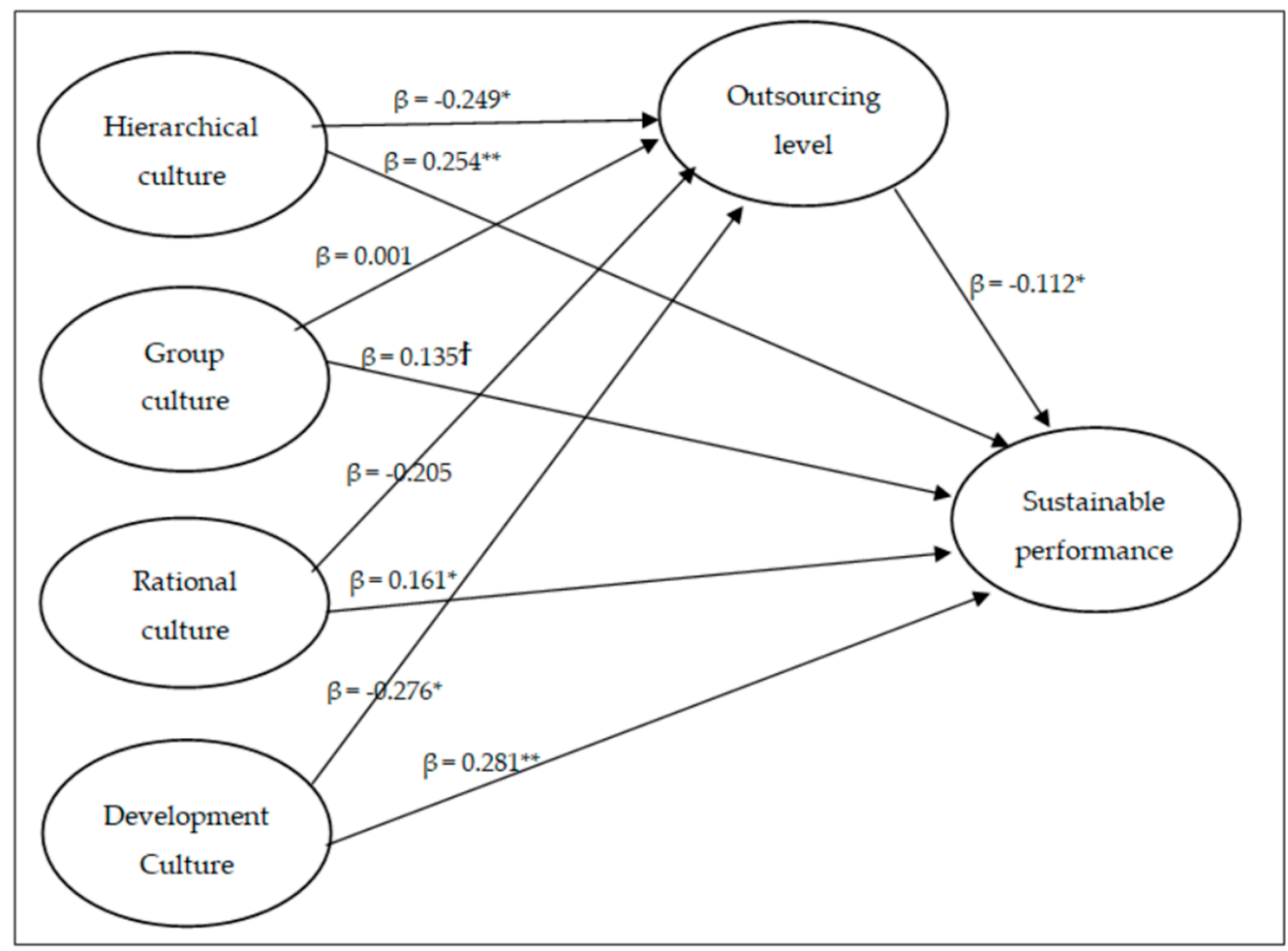

Figure 3. Structural Model. ${ }^{* *} p<0.01,{ }^{*} p<0.05,+p<0.10$.

For hypotheses $\mathrm{H} 2 \mathrm{a}$ and $\mathrm{H} 2 \mathrm{~b}$ about the influence of the group culture on the level of outsourcing and sustainable performance, the results show that this culture does not significantly influence the level of outsourcing ( $\beta=0.001, p>0.05$ ), but it has some positive influence, with $10 \%$ significance, on sustainable performance $(\beta=0.135, p<0.10$ ). Therefore, we only relatively confirm hypothesis $\mathrm{H} 2 \mathrm{~b}$ from our model, whereas hypothesis $\mathrm{H} 2 \mathrm{a}$ is not accepted.

In relation to $\mathrm{H} 3 \mathrm{a}$, the results $(\beta=-0.205, p<0.10)$ show that the rational culture has a certain negative and significant influence, at $10 \%$, on the level of outsourcing. This is contrary to the prediction because H3a suggests a positive relationship between the rational culture and outsourcing. However, in hypothesis $\mathrm{H} 3 \mathrm{~b}$, the rational culture has a positive effect on sustainable performance, with ( $\beta=0.161$, $p<0.05$ ), and so we can confirm hypothesis $\mathrm{H} 3 \mathrm{~b}$ from our model.

With regard to hypothesis $\mathrm{H} 4 \mathrm{a}$, which predicts that the development culture has a positive influence on the level of outsourcing, the results show that the relationship is negative ( $\beta=-0.276$, $p<0.05)$. Therefore, hypothesis $\mathrm{H} 4 \mathrm{a}$ is rejected, which indicates that a development culture negatively 
influences the level of outsourcing. However, there is a positive relationship between the development culture and sustainable performance $(\beta=0.281, p<0.01)$, and so we can accept hypothesis H4b.

Finally, hypothesis H5, which refers to the impact of the level of outsourcing on sustainable performance, is rejected because its impact is negative and significant $(\beta=-0.112, p<0.05)$.

\section{Conclusions}

The purpose of this study was to analyze the impact of four types of organizational culture - hierarchical, group, rational, and development—on the level of outsourcing and sustainable performance. To achieve this objective, the CVF framework was used, which provides insight into the way the ideological foundations and approach of each culture influence the level of outsourcing and sustainable performance.

Based on this impact and relationship, it was predicted that the organizational culture could positively and negatively influence the degree of outsourcing, depending on the type of culture. The idea is to reflect which types of organizational culture might favor the use of external suppliers, and to what extent the organizational culture plays a relevant role in sustainable performance, as well as the impact of outsourcing on results related to sustainable performance. No studies in the hotel context have investigated the relationships between these three concepts-organizational culture, outsourcing and sustainable performance-which gives added value to the results obtained.

Before analyzing the results, it should be kept in mind that outsourcing in Egypt is in its infancy, which means that hotels are now examining and testing outsourcing strategies in an attempt to maximize their profits, reduce their risks, and exchange information and experiences with these companies [115]. For this reason, the conclusions obtained are just referred to the Egyptian hotel sector as the outsourcing practice might hold other different characteristics in other tourist destinations.

This outsourcing immaturity indicates that few suppliers are quality firms, forcing hotels to seek and identify reliable and capable firms taking into account several factors, such as experience, past performance, and the company's culture and values [7]. When contracting an external supplier, hotels must adopt intercultural management approaches to achieve successful outsourcing because the organizational cultures of the hotel and the external supplier may be incompatible due to having different work processes, policies, strategies, objectives, and values. Therefore, the relationship between them should be strengthened through ongoing communication, frequent meetings, mutual trust, and transparency.

The results of this study are mixed because not all the proposed hypotheses are supported, and some of them even show the opposite of what was predicted. Regarding the impact of the organizational culture on outsourcing, the results indicate that the hierarchical culture has a negative impact on the level of outsourcing. In this regard, the results are consistent with those obtained by Zoghbi and Ting-Ding [116] when they point out that, in the hierarchical culture, there is greater task conflict between internal employees and outsourced personnel. For this reason, it is possible that hotels where the hierarchical culture predominates have a lower level of outsourcing.

Furthermore, this negative influence is due to the nature of the hierarchical culture, which is characterized by excessive control and strict rules and procedures in managing the hotel. Outsourcing implies a loss of control and autonomy [64,117], which leads these hotels with a hierarchical culture that focuses on control and rules to rely less on external suppliers. As a result, internal and external employees are not encouraged to participate or act flexibly when developing work processes.

Another result that stands out in this research is the negative impact of the development culture on the level of outsourcing. This means that hotels that use innovative strategies and an orientation towards creation and development have a lower level of outsourcing. According to Espino-Rodríguez et al. [118], due to outsourcing, the hotel may be unable to develop learning and exploit technological advances, and it may lose some basic skills and capacities. Furthermore, McIvor [3] suggests that outsourcing can lead to a loss of innovation potential and service quality, which signifies a reduction in hotel performance and a loss of the necessary skills to exploit new opportunities. 
In the case of the group culture, the results show that the group culture does not significantly influence the level of outsourcing, suggesting that there is no direct relationship between the group culture and outsourcing. The prediction we made about this type of culture was that it would have a negative influence on outsourcing. However, the group culture does not favor or hinder outsourcing, possibly because this culture might include external suppliers as members of the company who form part of the production process, in addition to maintaining close relationships with them. Hotels that prioritize the group culture have other reasons for outsourcing activities, apart from the typical characteristics of this culture.

Finally, the results suggest a certain negative influence, but to a lesser extent, of the rational culture on the level of outsourcing. This negative impact is due to the control this culture exerts on work processes and employee behaviors in following the strategies that make it possible to reach the objectives. Therefore, these issues keep external suppliers from participating in the strategies or jointly developing the objectives. In addition, for Doran et al. [119], this kind of culture makes internal employees extremely concerned about doing their tasks well in an effort to achieve the objectives. This makes coordination and communication with external staff difficult. Therefore, this type of hotel may also reject outsourcing because of a lack of confidence in the way external suppliers carry out their processes. In this regard, Zoghbi and Ting-Ding [116] show that in a rational culture there is a greater degree of relational conflict and task conflict between internal and external staff, which can lead to less outsourcing in hotels with a rational culture.

In the case of sustainable performance, the results show that all the types of organizational culture positively affect sustainable performance. First, the findings reveal that the development culture has the most influence on sustainable performance, due to the nature of this culture and its relationship with the environment. According to Linnenluecke and Griffiths [32], this culture is the one most interested in environmental and sustainable ideas and trends. Moreover, the results of Sugita and Takahashi's [86] study suggest that the most successful companies in terms of sustainability strategies are those that have a development culture, as well as those with a hierarchical culture. Hotels with a development culture pursue practices of sustainable performance aimed at the efficient use of their skills and knowledge for environmental concerns, the use of renewable energy, and the development or acquisition of technology for marketing strategies or processes and services.

Second, the results of our study demonstrate the positive influence of the hierarchical culture on sustainable performance, whereas previous studies Cameron and Quinn [61], Senge et al. [69] and Griffiths and Petrick [66] suggest a negative impact and lack of interest of hierarchical culture in sustainable performance. In the hierarchical culture, efficiency and profitability are the most valued parameters [61]. In this regard, this significant influence between the hierarchical culture and sustainable performance may be due to the fact that this culture focuses on the economic approach (economic sustainability) by concentrating on growth and profitability. For this reason, a hierarchical culture can favor sustainability and generate short-term profits, mainly economic, for the company [32]. Hotels that are oriented towards this culture can take advantage of their strict atmosphere to engage in environmentallyfriendly alternative technologies, best practices for more efficient use of resources, such as water and electricity, and cleaner production (reducing pollution), thus reducing the environmental impact and lowering the hotel's costs in the short term [120,121]. These practices are considered the first steps towards sustainability [122]. Similar results are obtained in the study by Abett et al. [123], who demonstrate the positive impact of the hierarchical culture on sustainability due to the strict rules managers adopt related to sustainability. In addition, Sugita and Takahashi [86] highlight the important role the hierarchical culture plays in aspects related to sustainability and the environment through managers' positive perception and interest in designing sustainability strategies.

Third, the hypothesis that establishes the positive impact of the rational culture on sustainable performance is confirmed. According to Scott [41], this culture fosters the efficient use of resources, competitiveness, and planning, which favors a broad vision of the environment and a move towards 
sustainability in fulfilling the company's objectives. This positive relationship consists of service innovation, adaptation to changes in consumer preferences and new market conditions, cost reduction, image improvements, and increases in efficiency and the hotel's reputation [32,124].

Finally, the results suggest that the group culture has a positive influence on sustainable performance. This positive impact is due to the nature of this culture, which focuses on employees, the development of their knowledge and skills, and other aspects such as cohesion, loyalty, and moral commitment. These principles motivate employees to be more sensitive to environmental issues and to use their skills to find ways to improve sustainability [32]. The results showing the positive impact of the group culture on sustainable performance are consistent with those found by Del Rosario and René [124], who demonstrate the significant influence of the group culture on eco-innovation.

Regarding the relationship between the level of outsourcing and sustainable performance, the results of our study show that the outsourcing level has a negative influence on sustainable performance. There are several possible reasons for this negative impact, including the limited capacities of external suppliers in this tourism destination and the high cost of performing activities aimed at sustainable performance. Hotels might reject these practices because they are probably more interested in reducing costs. Outsourcing is detrimental to sustainable performance; that is, hotels that choose to outsource have worse sustainable performance than those with less outsourcing. This aspect is quite worrisome because it indicates that outsourcing does not favor a more sustainable hotel, probably because outsourcing is not done with social and ethical demands or ecological criteria in mind. It also shows that hotels that outsource develop fewer resources and capacities in certain areas, which makes them less interested in sustainable development. These results are consistent with those obtained in the study by Espino-Rodríguez and Ramírez-Fierro [89], who suggest that outsourcing strategies do not positively affect certain non-financial aspects related to job quality and satisfaction.

\subsection{Academic and Practical Implications}

This research, through its structural model, contributes novel implications, both theoretical and practical, to the literature related to outsourcing and sustainable performance from the perspective of organizational culture. The results obtained can be quite useful for hotels in adapting their strategies and achieving success in outsourcing and sustainable performance.

From an academic point of view, the paper shows that the competing values framework (CVF) is valid to explain the level of outsourcing. It shows that certain types of culture have a negative influence on outsourcing. There are no papers in the literature that analyze the impact of culture on outsourcing and sustainable performance. The CVF is also a valid framework for explaining sustainable performance. The negative influence of outsourcing on sustainable performance can hinder a sustainable competitive advantage. This research contributes to developing a sound theoretical framework with which to better understand the determinants of outsourcing from the perspective of organizational culture and sustainable performance.

With regard to the implications for practitioners, this study generates knowledge and assists managers with outsourcing decisions, based on the type of organizational culture they follow. Depending on the type of culture, hotels will engage in outsourcing to a greater or lesser degree. Moreover, although all the cultures influence sustainable performance, a more innovation-oriented culture has the greatest impact on social and ethical demands, as well as on ecology. Thus, to obtain more sustainable hotels, managers should promote relevant aspects of the development culture, such as creativity, flexibility, and entrepreneurship. Furthermore, this study reveals the importance of creating a collaborative culture within the hotel that accepts external suppliers and gives them a space to carry out their work in the best possible way without harming sustainability. On the one hand, managers should be concerned not only with outsourcing, but also with the implementation phase. They should maintain inter-organizational relationships based on trust, so that external members become part of the company culture, in order to avoid undermining sustainability. At the time of the study, it was noted that there were no suppliers capable of improving sustainability. Outsourcing is a dynamic 
strategy that changes over time, and so managers must constantly evaluate their evolution in the different aspects related to sustainable performance. On the other hand, the findings of this study indicate that external suppliers must develop the necessary skills and capacities to achieve the hotel's objectives, and they must be more aware of sustainability and environmental issues. There should also be an atmosphere of cooperation with hotels to coordinate work processes and tasks. In addition, suppliers should keep hotels informed of new technologies and continuous changes in social, ethical, and environmental issues.

\subsection{Limitations and Future Research}

The present study has some limitations that may lead to future research. The results of thisstudy can only be generalized to the chosen hotel sector. The results and conclusions of this research only concern hotel accommodation from two cities in Egypt. Therefore, studies that test the hypotheses of the proposed model in other destinations or even in sectors other than tourism would be desirable. This would allow the theoretical relationships between culture, outsourcing, and sustainable performance established in this study to be strengthened and contrasted. Future studies should consider the relationship between organizational culture and outsourcing and sustainability by considering other organizational culture classifications in the literature. It is also important to be cautious in interpreting the results on sustainability because this study has not taken into account the practices hotels use to become more sustainable. Therefore, future research should study, in the same tourism destination, the impact of outsourcing on sustainability practices, and not just on performance, as in this paper. It is important to know external suppliers' degree of responsiveness to sustainability issues because they are considered key participants in the development of a competitive advantage. Another limitation is that the results are based on the point of view of management, which can produce bias. Therefore, future studies should analyze perceptions of sustainable performance from the point of view of customers.

Author Contributions: Conceptualization, M.G.T. and T.F.E.-R.; Data collection, M.G.T.; Literature review, M.G.T., methodology, T.F.E.-R., writing-original draft preparation, M.G.T. and T.F.E.-R. writing -review and editing, T.F.E.-R. All authors have read and agreed to the published version of the manuscript.

Funding: This research received no external funding.

Conflicts of Interest: The authors declare no conflict of interest.

\section{Appendix A}

\begin{tabular}{cr}
\hline Code & Factors \\
\hline HC_1 & Hierarchical Culture \\
\hline HC_2 & We emphasize efficiency and control to reach predictable performance results. \\
\hline- & Reliable delivery, smooth scheduling and low-cost production are the main focus. \\
\hline HC_3 & Our management style prioritizes conformity, predictability and stability. \\
\hline- & Even small matters have to be referred to someone higher up for a final answer. \\
\hline GC_1 & The development of human resources and concern about employee are highly valued. \\
\hline GC_2 & Our employees are encouraged to work as a team, exchange opinions, experiences and ideas. \\
\hline GC_3 & Employees can openly discuss their opinions and ideas with someone higher up. \\
\hline GC_4 & Employees are encouraged to take decisions. \\
\hline
\end{tabular}




\begin{tabular}{|c|c|}
\hline Code & Factors \\
\hline & Rational Culture \\
\hline RC_1 & Success defined on the basis of winning and leading in the marketplace. \\
\hline RC_2 & Our reward system encourages reaching hotel goals. \\
\hline RC_3 & We are results oriented, people are very competitive and achievement oriented. \\
\hline RC_4 & Objectives and aims are clearly defined. \\
\hline \multirow[t]{2}{*}{ RC_5 } & $\begin{array}{c}\text { Our management style is characterized by hard driving competitiveness, high demands and } \\
\text { individual achievement. }\end{array}$ \\
\hline & Developmental Culture \\
\hline DC_1 & We emphasize prospecting for opportunities and creating new challenges. \\
\hline DC_2 & $\begin{array}{l}\text { We make an effort to anticipate the potential aspects of new service manufacturing practices } \\
\text { and technologies. }\end{array}$ \\
\hline DC_3 & We are a very dynamic entrepreneurial place, which leads people to taking risks. \\
\hline DC_4 & Our management style is characterized by individual risk-taking, innovation, freedom, and uniqueness. \\
\hline \multirow[t]{2}{*}{ DC_5 } & We define success on the basis of innovation and having newest services. \\
\hline & Outsourcing level \\
\hline OL_1 & A large part of this hotel's personnel come from contracted services. \\
\hline OL_2 & Many departments in my hotel depend on external companies. \\
\hline OL_3 & The volume of services that this hotel has outsourced is high. \\
\hline OL_4 & A large number of my co-workers are subcontracted workers. \\
\hline \multirow[t]{2}{*}{ OL_5 } & A high percentage of staff members are external workers. \\
\hline & Sustainable performance \\
\hline SP_1 & We are the first that offer environmental-friendly services at the marketplace. \\
\hline SP_2 & Our competitors consider us as a leading hotel in the field of sustainability. \\
\hline SP_3 & $\begin{array}{l}\text { We develop new services or improve existing services that are regarded as sustainable for society } \\
\text { and environment. }\end{array}$ \\
\hline SP_4 & Our reputation in terms of sustainability is better than the sustainability reputation of our competitors. \\
\hline SP_5 & Compared to our competitors, we more thoroughly respond to societal and ethical demands. \\
\hline
\end{tabular}

Note: The items that are not numbered were eliminated from the analysis due to having factor loadings below 0.50.

\section{References}

1. Altin, M.; Uysal, M.; Schwartz, Z. Revenue management outsourcing: A hybrid model of transaction cost economics and organizational capability. Cornell Hosp. Q. 2017, 59, 112-124. [CrossRef]

2. Lamminmaki, D. An examination of factors motivating hotel outsourcing. Int. J. Hosp. Manag. 2011, 30, 963-973. [CrossRef]

3. McIvor, R. The Outsourcing Process. Strategies for Evaluation and Management; Cambridge University Press: Cambridge, UK, 2005.

4. Espino-Rodríguez, T.F.; Padrón-Robaina, V. A resource-based view of outsourcing and its implications for organizational performance in the hotel sector. Tour. Manag. 2005, 26, 707-721. [CrossRef]

5. Bolat, T.; Yılmaz, Ö. The relationship between outsourcing and organizational performance. Int. J. Contemp. Hosp. Manag. 2009, 21, 7-23. [CrossRef]

6. Hiamey, S.E.; Amenumey, E.K. Exploring service outsourcing in 3-5 Star hotels in the Accra Metropolis of Ghana. Tour. Manag. Perspect. 2013, 8, 9-17. [CrossRef]

7. Lam, T.; Han, M.X. A study of outsourcing strategy: A case involving the hotel industry in Shanghai, China. Int. J. Hosp. Manag. 2005, 24, 41-56. [CrossRef] 
8. Dorasamy, M.; Marimuthu, M.; Jayabalan, J.; Raman, M.; Kaliannan, M. Critical factors in outsourcing of accounting functions in Malaysian small medium-sized enterprises (smes). Kajianmalaysia: J. Malays. Stud. 2010, 28, 39-69.

9. Espino-Rodríguez, T.F.; Gil-Padilla, A.M. Determinants of information systems outsourcing in hotels from the resource-based view: An empirical study. Int. J. Tour. Res. 2005, 7, 35-47. [CrossRef]

10. Alofan, F.; Chen, S.; Tan, H. National cultural distance, organizational culture, and adaptation of management innovations in foreign subsidiaries: A fuzzy set analysis of TQM implementation in Saudi Arabia. J. Bus. Res. 2020, 109, 184-199. [CrossRef]

11. Sigler, T.H.; Pearson, C.M. Creating an empowering culture: Examining the relationship between organizational culture and perceptions of empowerment. J. Qual. Manag. 2000, 5, 27-52. [CrossRef]

12. Hemmington, N.; King, C. Key dimensions of outsourcing hotel food and beverage services. Int. J. Contemp. Hosp. Manag. 2000, 12, 256-261. [CrossRef]

13. Kshetri, N. Institutional factors affecting offshore business process and information technology outsourcing. J. Int. Manag. 2007, 13, 38-56. [CrossRef]

14. Çiçek, I.; Özer, B. The effect of outsourcing human resource on organizational performance: The role of organizational culture. Int. J. Bus. Manag. Stud. 2011, 3, 131-144.

15. Collins, C.M.; Steg, L.; Koning, M.A.S. Customers' values, beliefs on sustainable corporate performance, and buying behavior. Psychol. Mark. 2007, 24, 555-577. [CrossRef]

16. Jones, P.; Hillier, D.; Comfort, D. Sustainability in the hospitality industry. Int. J. Contemp. Hosp. Manag. 2016, 28, 36-67. [CrossRef]

17. Dunphy, D.; Griffiths, A.; Benn, S. Organizational Change for Corporate Sustainability: Understanding Organizational Change; Routledge: New York, NY, USA, 2003.

18. Freeman, E.R. The Stakeholder Approach Revisited. Z. Wirtsch. Unternehm. 2004, 5, 228-241. [CrossRef]

19. Crane, A. Corporate greening as amoralization. Organ. Stud. 2000, 21, 673-696. [CrossRef]

20. Welford, R. Environmental Strategy and Sustainable Development: The Corporate Challenge for the 21st Century; Routledge: London, UK, 1995.

21. Post, J.E.; Altma, B.W. Managing the environmental change process: Barriers and opportunities. J. Organ. Chang. Manag. 1994, 7, 64-81. [CrossRef]

22. Michel, M.J.P.I.; Velarde-Valdez, M.; Olmos-Martínez, E.; Santillan-Nuñez, M.A. Evaluación de la cultura organizacional en empresas hoteleras sostenibles de Mazatlán. Rev. Investig. Tur. 2019, 17, 71. [CrossRef]

23. Willard, B. The Sustainability Advantage: Seven Business Case Benefits for a Triple Bottom Line; New Society Publishers: Gabriola Island, BC, Canada, 2002.

24. Esty, D.C.; Andrew, S. Winston. In Green to Gold: How Smart Companies Use Environmental Strategy to Innovate, Create Value, and Build Competitive Advantage; Yale University Press: New Haven, CT, USA; London, UK, 2006.

25. Haanaes, K.; Michael, D.; Jurgens, J.; Rangan, S. Making sustainability profitable. Harv. Bus. Rev. 2013, 91, 110-115.

26. Schaltegger, S.; Hansen, E.G.; Lüdeke-Freund, F. Business models for sustainability: Origins, present research, and future avenues. Organ. Environ. 2015, 29, 3-16. [CrossRef]

27. Isensee, C.; Teuteberg, F.; Griese, K.-M.; Topi, C. The relationship between organizational culture, sustainability, and digitalization in SMEs: A systematic review. J. Clean. Prod. 2020, 275, 122944. [CrossRef]

28. Yaprak, A.; Tasoluk, B.; Kocas, C. Market orientation, managerial perceptions, and corporate culture in an emerging market: Evidence from Turkey. Int. Bus. Rev. 2015, 24, 443-456. [CrossRef]

29. Jogaratnam, G. How organizational culture influences market orientation and business performance in the restaurant industry. J. Hosp. Tour. Manag. 2017, 31, 211-219. [CrossRef]

30. Frost, P.J.; Kaiser, E.F.; Quinn, R.E. Beyond rational management: Mastering the paradoxes and competing demands of high performance. Acad. Manag. Rev. 1989, 14, 462. [CrossRef]

31. Prajogo, D.I.; McDermott, C.M. The relationship between total quality management practices and organizational culture. Int. J. Oper. Prod. Manag. 2005, 25, 1101-1122. [CrossRef]

32. Linnenluecke, M.K.; Griffiths, A. Corporate sustainability and organizational culture. J. World Bus. 2010, 45, 357-366. [CrossRef]

33. Gelhard, C.V.; Von Delft, S. The role of organizational capabilities in achieving superior sustainability performance. J. Bus. Res. 2016, 69, 4632-4642. [CrossRef] 
34. Sousa, R.; Voss, C. Contingency research in operations management practices. J. Oper. Manag. 2008, 26, 697-713. [CrossRef]

35. Child, J. Culture, contingency and capitalism in the cross national study of organizations. In Research in Organizational Behavior; Cummings, L.L., Staw, B.M., Eds.; JAI Press: Greenwich, CT, USA, 1981; Volume 3, pp. 303-356.

36. Pettigrew, A.M. On studying organizational cultures. Adm. Sci. Quart. 1979, 24, 570-581. [CrossRef]

37. Cadden, T.; Marshall, D.; Cao, G. Opposites attract: Organisational culture and supply chain performance. Supply Chain Manag. Int. J. 2013, 18, 86-103. [CrossRef]

38. Denison, D.R.; Mishra, A.K. Toward a theory of organizational culture and effectiveness. Organ. Sci. 1995, 6, 204-223. [CrossRef]

39. Detert, J.R.; Schroeder, R.G.; Mauriel, J.J. A framework for linking culture and improvement initiatives in organizations. Acad. Manag. Rev. 2000, 25, 850-863. [CrossRef]

40. Wu, S.J.; Zhang, D.; Schroeder, R.G. Customization of quality practices: The impact of quality culture. Int. J. Qual. Reliab. Manag. 2011, 28, 263-279. [CrossRef]

41. Scott, W.R. Organizations: Rational, Natural, and Open Systems; Prentice-Hall: Upper Saddle River, NJ, USA, 2003.

42. Hofstede, G. Culture's Consequences: Comparing Values, Behaviours, Institutions and Organizations across Nations, 2nd ed.; Sage Publications: Thousand Oaks, CA, USA, 2001.

43. Sathe, V. Culture and Related Corporate Realities: Text, Cases, and Readings on Organizational Entry, Establishment, and Change; Richard D Irwin: Homewood, IL, USA, 1985.

44. Schein, E.H. Coming to a new awareness of organizational culture. Sloan Manag. Rev. 1984, 25, 3-16.

45. Deal, T.; Kennedy, A. The New Corporate Cultures: Revitalizing the Workplace after Downsizing. Mergers, and Reengineering; Perseus: Cambridge, MA, USA, 1999.

46. Tierney, W.G.; Schein, E.H. Organizational CULTURE AND LEADERSHIP. Acad. Manag. Rev. 1986, $11,677$. [CrossRef]

47. Barney, J.B. Organizational culture: Can it be a source of sustained competitive advantage? Acad. Manag. Rev. 1986, 11, 656-665. [CrossRef]

48. O'Reilly, C. Corporations, culture, and commitment: Motivation and social control in organizations. Calif. Manag. Rev. 1989, 31, 9-25. [CrossRef]

49. Chatman, J.A.; Jehn, K.A. Assessing the relationship between industry characteristics and organizational culture: How different can you be? Acad. Manag. J. 1994, 37, 522-553. [CrossRef]

50. Tarba, S.Y.; Ahammad, M.F.; Junni, P.; Stokes, P.; Morag, O. The impact of organizational culture differences, synergy potential, and autonomy granted to the acquired high-tech firms on the M\&A performance. Group Organ. Manag. 2017, 44, 483-520. [CrossRef]

51. González-Rodríguez, M.R.; Martín-Samper, R.C.; Köseoglu, M.A.; Okumus, F. Hotels' corporate social responsibility practices, organizational culture, firm reputation, and performance. J. Sustain. Tour. 2019, 27, 398-419. [CrossRef]

52. Quinn, R.E.; Spreitzer, G.M. The psychometrics of the competing values culture instrument and an analysis of the impact of organizational culture on quality of life. Res. Organ. Chang. Dev. 1991, 5, 115-142.

53. Leisen, B.; Lilly, B.; Winsor, R.D. The effects of organizational culture and market orientation on the effectiveness of strategic marketing alliances. J. Serv. Mark. 2002, 16, 201-222. [CrossRef]

54. Gregory, B.T.; Harris, S.G.; Armenakis, A.A.; Shook, C.L. Organizational culture and effectiveness: A study of values, attitudes, and organizational outcomes. J. Bus. Res. 2009, 62, 673-679. [CrossRef]

55. Zu, X.; Robbins, T.L.; Fredendall, L.D. Mapping the critical links between organizational culture and TQM/Six Sigma practices. Int. J. Prod. Econ. 2010, 123, 86-106. [CrossRef]

56. Yeung, A.K.; Brockbank, J.W.; Ulrich, D. Organizational culture and human resource practices: An empirical assessment. Res. Organ. Chang. Dev. 1991, 5, 59-81.

57. Naor, M.; Goldstein, S.M.; Linderman, K.W.; Schroeder, R.G. The role of culture as driver of quality management and performance: Infrastructure versus core quality practices*. Decis. Sci. 2008, 39, 671-702. [CrossRef]

58. Quinn, R.E.; McGrath, M.R. The transformation of organizational cultures: A competing values perspective. In Organizational Culture; Frost, P.J., Moore, L.F., Louis, M.R., Lundberg, C.C., Martin, J., Eds.; Sage Publications: Beverly Hills, CA, USA, 1985; pp. 295-313. 
59. Denison, D.R.; Spreitzer, G.M. Organizational culture and organizational development: A competing values approach. Res. Organ. Chang. Dev. 1991, 5, 1-21.

60. McDermott, C.M.; Stock, G.N. Organizational culture and advanced manufacturing technology implementation. J. Oper. Manag. 1999, 17, 521-533. [CrossRef]

61. Cameron, K.; Quinn, R.E. Diagnosing and Changing Organizational Culture (EdiciónRevisada); Jossey-Bass: San Francisco, CA, USA, 2006.

62. Braunscheidel, M.J.; Suresh, N.C.; Boisnier, A.D. Investigating the impact of organizational culture on supply chain integration. Hum. Resour. Manag. 2010, 49, 883-911. [CrossRef]

63. Ruppel, C.P.; Harrington, S.J. Sharing knowledge through intranets: A study of organizational culture and intranet implementation. IEEE Trans. Dependable Secur. Comput. 2001, 44, 37-52. [CrossRef]

64. Espino-Rodríguez, T.F.; Ramírez-Fierro, J.C. Managers' attitudes toward hotel outsourcing in a tourist destination. An approach from the benefits and risks perspective. Tour. Manag. Perspect. 2018, 26, 143-152. [CrossRef]

65. Quinn, R.E.; Kimberly, J.R. Paradox, planning and perseverance: Guidelines for managerial practice. In Managing Organizational Transitions; Kimberly, J.R., Quinn, R.E., Eds.; Dow Jones-Irwin: Homewood, IL, USA, 1984; pp. 295-313.

66. Griffiths, A.; Petrick, J.A. Corporate architectures for sustainability. Int. J. Oper. Prod. Manag. 2001, 21, 1573-1585. [CrossRef]

67. Ramus, C.A. Context and values: Defining a research agenda for studying employee environmental motivation in business organizations. Corp. Environ. Strateg. Compet. Adv. 2015, 71-95. [CrossRef]

68. Aragón-Correa, J.A.; Sharma, S. A contingent resource-based view of proactive corporate environmental strategy. Acad. Manag. Rev. 2003, 28,71-88. [CrossRef]

69. Senge, P.M.; Carstedt, G.; Porter, P.L. Innovating our way to the next industrial revolution. MIT Sloan Manag. Rev. 2001, 42, 24-38.

70. Zhao, X.; Huo, B.; Selen, W.; Yeung, J.H.Y. The impact of internal integration and relationship commitment on external integration. J. Oper. Manag. 2011, 29, 17-32. [CrossRef]

71. Belcourt, M. Outsourcing-The benefits and the risks. Hum. Resour. Manag. Rev. 2006, 16, 269-279. [CrossRef]

72. Adler, P.S. Making the HR outsourcing decision. MIT Sloan Manag. Rev. 2003, 45, 53-60.

73. Elmuti, D.; Grunewald, J.; Abebe, D. Consequences of outsourcing strategies on employee quality of work life, attitudes, and performance. J. Bus. Strategy 2010, 27, 177-203.

74. Domberger, S. The Contracting Organization: A Strategic Guide to Outsourcing; Oxford University Press: Oxford, UK, 1998.

75. Kakabadse, N.; Kakabadse, A. Critical review-Outsourcing: A paradigm shift. J. Manag. Dev. 2000, 19, 670-728. [CrossRef]

76. Geishecker, I. The impact of international outsourcing on individual employment security: A micro-level analysis. Labour Econ. 2008, 15, 291-314. [CrossRef]

77. Daily, B.F.; Huang, S. Achieving sustainability through attention to human resource factors in environmental management. Int. J. Oper. Prod. Manag. 2001, 21, 1539-1552. [CrossRef]

78. Lambert, D.M.; Cooper, M.C. Issues in supply chain management. Ind. Mark. Manag. 2000, $29,65-83$. [CrossRef]

79. Bowersox, D.J.; Closs, D.J.; Stank, T.P. How to master cross-enterprise collaboration. Supply Chain Manag. Rev. $2003,7,18-27$.

80. Wong, C.Y.; Boon-Itt, S. The influence of institutional norms and environmental uncertainty on supply chain integration in the Thai automotive industry. Int. J. Prod. Econ. 2008, 115, 400-410. [CrossRef]

81. Barley, S.R.; Kunda, G. Design and devotion: Surges of rational and normative ideologies of control in managerial discourse. Adm. Sci. Q. 1992, 37, 363. [CrossRef]

82. Kaynak, H.; Hartley, J.L. A replication and extension of quality management into the supply chain. J. Oper. Manag. 2008, 26, 468-489. [CrossRef]

83. Holcomb, T.R.; Hitt, M.A. Toward a model of strategic outsourcing. J. Oper. Manag. 2006, 25, 464-481. [CrossRef]

84. Sharma, S.; Starik, M. Research in corporate sustainability: The evolving theory and practice of organizations in the natural environment. Can. J. Adm. Sci. 2009, 21, 288-289. [CrossRef]

85. Carroll, A.B. Corporate social responsibility. Bus. Soc. 1999, 38, 268-295. [CrossRef] 
86. Sugita, M.; Takahashi, T. Influence of corporate culture on environmental management performance: An empirical study of Japanese firms. Corp. Soc. Responsib. Environ. Manag. 2013, 22, 182-192. [CrossRef]

87. Hart, S.L.; Dowell, G. Invited editorial: A natural-resource-based view of the firm: Fifteen years after. J. Manag. 2011, 37, 1464-1479. [CrossRef]

88. Pujari, D. Eco-innovation and new product development: Understanding the influences on market performance. Technovation 2006, 26, 76-85. [CrossRef]

89. Espino-Rodríguez, T.F.; Ramírez-Fierro, J.C. The relationship between strategic orientation dimensions and hotel outsourcing and its impact on organizational performance. An application in a tourism destination. Sustainability 2018, 10, 1769. [CrossRef]

90. Kiron, D.; Kruschwitz, N.; Haanaes, K.; Reeves, M.; Fuisz-Kehrbach, S.K.; Kell, G. Joining forces: Collaboration and leadership for sustainability. MIT Sloan Manag. Rev. 2015, 56, 1-32.

91. Dekker, H.C.; Mooi, E.; Visser, A. Firm enablement through outsourcing: A longitudinal analysis of how outsourcing enables process improvement under financial and competence constraints. Ind. Mark. Manag. 2020, 90, 124-132. [CrossRef]

92. Selim, M.; Aidrous, I.; Semenova, E. International tourism: Prospects for development in the post coronavirus world (egyptian example). Int. J. Manag. 2020, 11, 1145-1155.

93. Gambi, L.D.N.; Boer, H.; Gerolamo, M.C.; Jørgensen, F.; Carpinetti, L.C.R. The relationship between organizational culture and quality techniques, and its impact on operational performance. Int. J. Oper. Prod. Manag. 2015, 35, 1460-1484. [CrossRef]

94. Morelli, J.J. Rochester Institute of Technology environmental sustainability: A definition for environmental professionals. J. Environ. Sustain. 2011, 1, 1-10. [CrossRef]

95. Ringle, C.M.; Sarstedt, M.; Mitchell, R.; Gudergan, S.P. Partial least squares structural equation modeling in HRM research. Int. J. Hum. Resour. Manag. 2020, 31, 1617-1643. [CrossRef]

96. Sarstedt, M.; Hair, J.F.; Ringle, C.M.; Thiele, K.O.; Gudergan, S.P. Estimation issues with PLS and CBSEM: Where the bias lies! J. Bus. Res. 2016, 69, 3998-4010. [CrossRef]

97. Bamgbade, J.A.; Kamaruddeen, A.M.; Nawi, M.N.M.; Yusoff, R.Z.; Bin, R.A. Does government support matter? Influence of organizational culture on sustainable construction among Malaysian contractors. Int. J. Constr. Manag. 2017, 18, 93-107. [CrossRef]

98. Hair, J.F., Jr.; Hult, G.T.M.; Ringle, C.; Sarstedt, M. A Primer on Partial Least Squares Structural Equation Modeling (PLS-SEM); Sage Publications: Thousand Oaks, CA, USA, 2017.

99. Ee, O.; Halim, H.A.; Ramayah, T. The effects of partnership quality on business process outsourcing success in Malaysia: Key users perspective. Serv. Bus. 2012, 7, 227-253. [CrossRef]

100. Teo, T.S.; Bhattacherjee, A. Knowledge transfer and utilization in IT outsourcing partnerships: A preliminary model of antecedents and outcomes. Inf. Manag. 2014, 51, 177-186. [CrossRef]

101. Haenlein, M.; Kaplan, A.M. A beginner's guide to partial least squares analysis. Underst. Stat. 2004, 3, 283-297. [CrossRef]

102. Roldán, J.L.; Sánchez-Franco, M.J. Variance-based structural equation modeling. Res. Methodol. Innov. Philos. Softw. Syst. Eng. Inf. Syst. 2012, 193-221. [CrossRef]

103. Barclay, D.W.; Higgins, C.; Thompson, R. The partial least squares approach to causal modeling: Personal computer adoption and use as illustration. Technol. Stud. 1995, 2, 285-309.

104. Fornell, C.; Larcker, D.F. Structural equation models with unobservable variables and measurement error: Algebra and statistics. J. Mark. Res. 1981, 18, 382. [CrossRef]

105. Tenenhaus, M.; Vinzi, V.E.; Chatelin, Y.-M.; Lauro, C. PLS path modeling. Comput. Stat. Data Anal. 2005, 48, 159-205. [CrossRef]

106. Carmines, E.G.; Zeller, R.A. Reliability and Validity Assessment; Sage Publications: Beverly Hills, CA, USA, $1979 ;$ p. 17.

107. Hulland, J. Use of partial least squares (PLS) in strategic management research: A review of four recent studies. Strateg. Manag. J. 1999, 20, 195-204. [CrossRef]

108. Henseler, J.; Ringle, C.M.; Sarstedt, M. A new criterion for assessing discriminant validity in variance-based structural equation modeling. J. Acad. Mark. Sci. 2015, 43, 115-135. [CrossRef]

109. Gold, A.H.; Malhotra, A.; Segars, A.H. Knowledge management: An organizational capabilities perspective. J. Manag. Inf. Syst. 2001, 18, 185-214. [CrossRef]

110. Falk, R.F.; Miller, N.B. A Primer for Soft Modeling; University of Akron Press: Akron, OH, USA, 1992. 
111. Stone, M. Cross-validation and multinomial prediction. Biometrika 1974, 61, 509-515. [CrossRef]

112. Geisser, S. The predictive sample reuse method with applications. J. Am. Stat. Assoc. 1975, 70, 320-328. [CrossRef]

113. Chin, W.W. The partial least squares approach to structural equation modeling. Mod. Methods Bus. Res. 1998, 295, 295-336.

114. Cohen, J. The t test for means. Statistical Power Analysis for the Behavioral Sciences, 2nd ed.; Lawrence Erlbaum Associates: New York, NY, USA, 1988; pp. 19-74. [CrossRef]

115. ElHoushy, S.; Salem, I.E.; Agag, G. The impact of perceived benefits and risks on current and desired levels of outsourcing: Hotel managers' perspective. Int. J. Hosp. Manag. 2020, 91, 102419. [CrossRef]

116. Zoghbi-Manrique-De-Lara, P.; Ting-Ding, J.-M. The influence of corporate culture and workplace relationship quality on the outsourcing success in hotel firms. Int. J. Hosp. Manag. 2016, 56, 66-77. [CrossRef]

117. Quinn, J.B.; Hilmer, F.G. Strategic outsourcing. MIT Sloan Manag. Rev. 1994, 35, 43-55.

118. Espino-Rodríguez, T.F.; Lai, P.-C.; Baum, T.; Baum, T. Risks and benefits of outsourcing hotel operations: A comparison between Scotland and Taiwan. Tour. Econ. 2012, 18, 95-120. [CrossRef]

119. Doran, M.S.; Haddad, K.M.; Chow, C.W. The relationship between corporate culture and performance in Bahrain hotels: Findings and management implications. Int. J. Hosp. Tour. Adm. 2004, 4, 65-80. [CrossRef]

120. Rahman, I.; Reynolds, D.; Svaren, S. How "green" are North American hotels? An exploration of low-cost adoption practices. Int. J. Hosp. Manag. 2012, 31, 720-727. [CrossRef]

121. Razumova, M.; Rey-Maquieira, J.; Lozano, J. The role of water tariffs as a determinant of water saving innovations in the hotel sector. Int. J. Hosp. Manag. 2016, 52, 78-86. [CrossRef]

122. The Organisation for Economic Co-Operation and Development (OECD). Green Innovation in Tourism Services; OECD Tourism Papers; OECD Publishing: Paris, France, 2013. [CrossRef]

123. Abett, L.; Coldham, A.; Whisnant, R. Organizational Culture and the Success of Corporate Sustainability Initiatives: An Empirical Analysis Using the Competing Values Framework. Master's Thesis, University of Michigan, Ann Arbor, MI, USA, 2010; pp. 1-68.

124. Del Rosario, R.-S.M.; Patricia, S.S.-M.; René, D.-P. Eco-innovation and organizational culture in the hotel industry. Int. J. Hosp. Manag. 2017, 65, 71-80. [CrossRef]

Publisher's Note: MDPI stays neutral with regard to jurisdictional claims in published maps and institutional affiliations.

(C) 2020 by the authors. Licensee MDPI, Basel, Switzerland. This article is an open access article distributed under the terms and conditions of the Creative Commons Attribution (CC BY) license (http://creativecommons.org/licenses/by/4.0/). 